\title{
Optimal concentration of mangrove (Rhizophora mucronata) leaf and propagule based natural dye
}

\author{
Delianis Pringgenies ${ }^{a, *}$, Ervia Yudiati ${ }^{a}$, Ria Azizah Tri Nuraini ${ }^{a}$, Endang Sri Susilo ${ }^{a}$, Edia \\ Rahayuningsih ${ }^{b}$ \\ ${ }^{a}$ Department of Marine Science, Faculty of Fisheries and Marine Science, Diponegoro University, Semarang, Indonesia \\ b Laboratory of Separation Processes, Chemical Engineering Department, Faculty of Engineering, Gajah Mada University, Yogyakarta, Indonesia \\ *Corresponding author: pringgenies@yahoo.com
}

\section{Article history}

Submitted 19 January 2018

Revised 12 February 2018

Accepted 5 March 2018

Published Online 30 April 2018

Graphical abstract

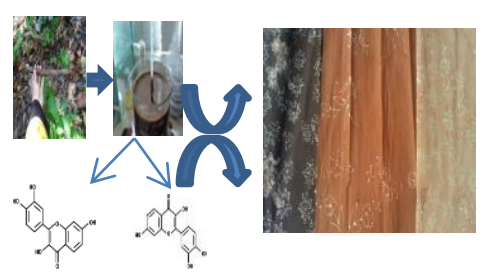

\begin{abstract}
This research aims to discover total extract level from leaf and propagule of mangrove Rhizophora mucronata, Baume relationship and extract level from leaf and propagule of mangrove, the result of color extract for fabric cotton, phytochemical screening of active compounds contained in mangroves and dye application by fractionation method using column chromatography. The methods employed in this study by means of Baume scale, gravimetric analysis of extract contents, phytochemical screening, and column gravity chromatography separated color of the pigment. The results showed that the higher the level of extract, the greater the mass of the species and the higher the level of extract, the color will be darker. During the soxhlet extraction process, water contents of the material were at $60 \%$ for fresh leaves, $18 \%$ for dehydrated leaves, $16 \%$ for mangrove fruit propagule, and $14 \%$ for mangrove branch propagule. Average dye contents were measured at $5 \%$ for fresh leaves, $22 \%$ for dehydrated leaves, $17 \%$ for mangrove fruit propagule, and $21 \%$ for mangrove branch propagule. The colors resulted from treatment of the samples using limestone, alum and lotus solutions from each mangrove leaf and propagule sample were different from white to dark brown. The optimal concentration of dye found in this study were $0.0071 \mathrm{~g} / \mathrm{mL}$ for fresh leaves, $0.0080 \mathrm{~g} / \mathrm{mL}$ for dehydrated leaves, $0.0255 \mathrm{~g} / \mathrm{mL}$ for fruit propagule, and 0.0275 $\mathrm{g} / \mathrm{mL}$ for branch propagule. Phytochemical test results also show that the pigment associated to the blackish-green hue was tannin, and that which was associated with red was flavonoid and quinone. The result of column chromatography showed that on leaf waste and skin is found in blackish green color and on the skin can be found in red.
\end{abstract}

Keywords: Column chromatography, dye concentration, leaves, Rhizophora mucronata

(c) 2018 Penerbit UTM Press. All rights reserved

\section{INTRODUCTION}

The effort of turning an ecological, socio-cultural and socioeconomical function of erosion zones into mangrove conservation areas is a promising coastal area rehabilitation project. One such rehabilitations often taking prominence as the main option is mangrove planting. Mangunhardjo village, Mangunhardjo sub-district, Mangkang area of Tugu District, Semarang city was a brackish water pond zone, which is suffering from the impact of climate change. Today, the area is often flooded by Beringin river and sea water overflow, locally known as "rob", significantly lowering the productivity of brackish water pond there. The contemporary living of the local community has shifted from brackish water aquafarm to land restoration into mangrove conservation area. The local coastal community regularly plants new seedlings, maintain, and trim mangrove trees. However, the conservation activity also produces waste in the form of mangrove leaves, branches, and propagules. The common methods in handling these wastes currently employed by the community are landfill and incineration. However, a new research has enabled the community to turn mangrove waste into natural dye for batik fabric (Pringgenies et al., 2013).

Batik has grown into prominence both in the local and international markets. The increasing market demands make batik producers turn into synthetic dye due to its good color retention and low cost of production. However, as the awareness for sustainable development and the use of environmentally friendly products increase, informed consumers gradually shift their interest in batik products with natural dye. It has been known that synthetic fabric dye can trigger topical cancer and its waste is damaging to the environment, being mutagenic and not easily degradable in nature (Agustina et al., 2011). Orange II is an example of a synthetic dye that is not easily degradable. The waste from textile industries which use synthetic dye in their production process has been known to contain heavy metals such as chromium, zinc, copper, etc (Indrianingsih, 2013). Not only these dangers will impact the environment, they will also impose upon the quality of health of the community of its users and those living near the production sites. The use of mangrove waste as a material for natural dye will alleviate the health hazard to the community as well as increase the income of coastal communities whose lives depend on mangrove zones.

Color pigments in the parts of $R$. mucronata (mangrove) tree can be used as materials for natural dye, yet little information is available on the variation of resulting colors and color retention. The application of this natural dye in batik production is not yet widespread as well. The use of $R$. mucronata as a material for batik natural dye has the potential to become an asset when properly applied in the industry, and it may contribute to the economic improvement for the community whose livelihood is tied to mangrove and batik industry. 
On the other hand, the durability of color fastness in the fabric cotton is the thing that really determines the quality of a product Many natural materials can produce natural dyes, but once applied to an existing fabric cotton, the color becomes reduced or faded. The problem must be overcome. Furthermore, the natural dyes with optimum dye concentration need to be investigated by doing the fixation. Fixation is the process of dyeing fabric so that the dyestuff absorbed in the fabric fibers produced not easily fade. Fixation is done by adding materials containing metal complexes, such as limestone, alum, and lotus (Pringgenies et al., 2013).

Based on these considerations, this study aims to discover the total extract level from leaf and propagule of mangrove $R$. mucronata, Baume relationship and extract level from leaf and propagule of mangrove, the result of color extract for fabric cotton, the relationship between Baume and extract contents of mangrove leaves and propagules, the resulting colors on the fabric, phytochemical screening of active compounds contents of mangrove and the result of natural dye application using fractionation method and application of coloring from the result of color separation by chromatography column method.

\section{EXPERIMENTAL}

The samples in this study consist of dry and fresh leaves, globular propagules and torpedo-shaped propagules from $R$. mисronata. Sample preparation, soxhlet extraction, alcohol solvent separation from mangrove solution, total content of mangrove extract measurement, extract concentration, sample extract measurements, extract density measurements using pycnometer and Baume scale, extract content measurements using gravimetric method (Bogoriani, N. W., 2010; Harbone, 1987).

\section{Fabric immersion and testing}

Cut, mordant-fixated fabric was immersed in each prepared extract sample. The tested extracts were dry leaf-based (5 concentrations), fresh leaf-based (5 concentrations), globular propagule-based (3 concentrations) and torpedo-shaped propagulebased (3 concentrations). Each fabric was immersed for 10 minutes, after which it was air-dried. This process was repeated twice.

\section{Fixation process}

Each immersed fabric was cut into two equally-sized parts. This process was carried out by immersing the fabric in a limestone solution $\left(\mathrm{Ca}(\mathrm{OH})_{2}\right)$, alum solution, and lotus solution for 30 minutes and then air-dried. The results were then compared.

\section{Phytochemical screening}

Ethanol extract of mangrove leaves and barks were put into phytochemical screening to determine their secondary metabolites contents. According to Harbone (1984), metabolite compounds commonly found in plants are saponin, tannin, flavonoids, quinones, alkaloids, steroids, and terpenoids. Saponin screening was performed by shaking $10 \mathrm{ml}$ of filtrate in a reaction tube for 5 seconds. Observation of visual changes was performed afterward. The formation of bubbles after the addition of dilute $\mathrm{HCl}$ confirms the positive reaction for saponin content. Tannin screening was performed by adding 5 drops of $\mathrm{FeCl}_{3} 1 \%$ to 0.5 grams of extract. The occurrence of dark blue or greenish black coloration confirmed the tannin content in the extract. Quinone screening was performed by introducing 5 drops of $\mathrm{NaOH}$ solution in $10 \mathrm{ml}$ filtrate. Red coloration showed the existence of quinone in the extract. Flavonoid screening employed 1 pulverized $\mathrm{Mg}$ and $190 \mathrm{ml}$ concentrated $\mathrm{HCl}$ in $1 \mathrm{ml}$ extract. Red coloration showed a positive result for flavonoid content. Alkaloid screening was performed by mixing $1 \mathrm{ml}$ of ethanol extract and 10 drops of $\mathrm{H}_{2} \mathrm{SO}_{4}$, of which the acid layer was then processed in another reaction tube. The sulfuric acid layer was introduced into drip plate and reacted with Dragendrof catalyst. Reddish orange coloration indicated the alkaloid content. Terpenoid and steroid screening was carried out by adding 3 drops of acetic anhydride and a drop of $\mathrm{H}_{2} \mathrm{SO}_{4}$ into $1 \mathrm{ml}$ extract. The occurrence of red coloration indicated terpenoid content, whereas blue coloration showed steroid content.

\section{Fractionation of mangrove waste-based dye}

To obtain distinct colors from the mangrove-based natural dye, the color separation was accomplished by means of column chromatography.

\section{RESULTS AND DISCUSSION}

This research studies the use of mangrove, namely its leaves and propagules, as basic materials for natural dye. Two treatments were employed for the leaves, namely dry and fresh, whereas the propagules were categorized based on their shape. These materials were cut into size.

\section{Fresh leaves test results}

Soxhlet extraction was performed to determine the total pigment content in a material. Prior to Soxhlet extraction, the water content of the materials was determined. The water content was determined by calculating the difference in material mass between measured at predrying and at the post-drying process and it is indicated in percent. The total mass of material dye content was determined by gravimetric measurement of extract content times the remaining extract volume, after which the total mass of dye was compared with initial material mass. For total mass measurements, $2 \mathrm{ml}$ was taken from each sample to determine its total mean mass. Water content in fresh mangrove leaves sample was measured at $60 \%$ (g of water/g of fresh leaves) whereas total dye content was determined at $4 \%$ (g of extract/g of fresh leaves) and $6 \%$ (g of extract/g of fresh leaves), making the mean dye content of $5 \%$ ( $\mathrm{g}$ of extract $/ \mathrm{g}$ of fresh leaves).

Concentration was made by using 5 of the samples for each material. Samples were tested using pycnometer, gravimetry and Baume scale. Samples of fresh leaves extract were collected at 12.5 $\mathrm{cm}, 9 \mathrm{~cm}, 4.7 \mathrm{~cm}, 3 \mathrm{~cm}$, and $500 \mathrm{ml}$ of pan level. Samples were simmered down and were measured for density and extract content using pycnometer and Baume scale. Test results were recorded into figures between pycnometer vs extract content and Baume scale vs extract content.

Based on the data in Fig. 1, the level of extract content in fresh leaves is proportionate to the density. This is in accordance with the theory which states that content and density are indicators of the total content of a material. The difference here lies in the content levels/concentration shows the content of a substance in the liquid. On the other hand, density shows the mass of material per volume unit. The relation between density and pycnometer $v s$ extract content of fresh mangrove leaves can be approached by the equation $y=0.561 x$ +0.984 .

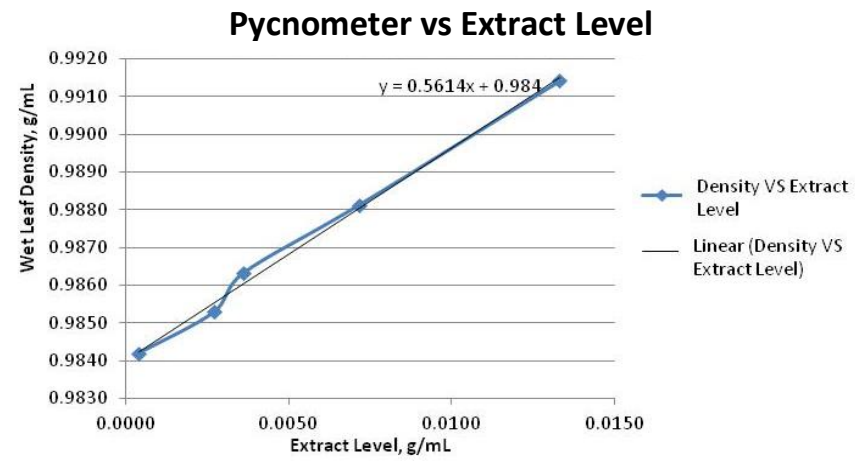

Fig. 1 Pycnometer vs extract content of fresh mangrove leaves.

Fig. 2 shows that the higher the extract content, the higher the Baume value in fresh mangrove leaves extract. The measurement of Baume aurometer for fresh mangrove leaves extract can be approached with the equation $y=139.8 x+0.120$, whereas for Baume hydrometer measurement can be approached by $y=152.3 x-0.127$. Baume salinity can be approached by the equation $y=111.7 x+0.073$. 
Data from Baume hydrometer measurements showed deviation where sample 1 showed 0.5 and sample 2 showed 0.2. Therefore, Baume hydrometer is not recommended for fresh leaves extract content measurement.

The results of the measurements showed that the content of extract and the measured density in mangrove leaves and propagules are proportionate to each other. This finding was different from the previous study on the measurement of Dracaena extract with ethanol solvent. The study found that length of extraction time is proportionate to the percentage of extracted chlorophyll, with a marked decrease after 3 hours (Yuniwati et al, 2012). On the other hand, extraction time did not have significant relationship with the amount of resulting amount of extracted pigment. However, mangrove waste immersion at longer times was observed to result in thicker and darker colors.

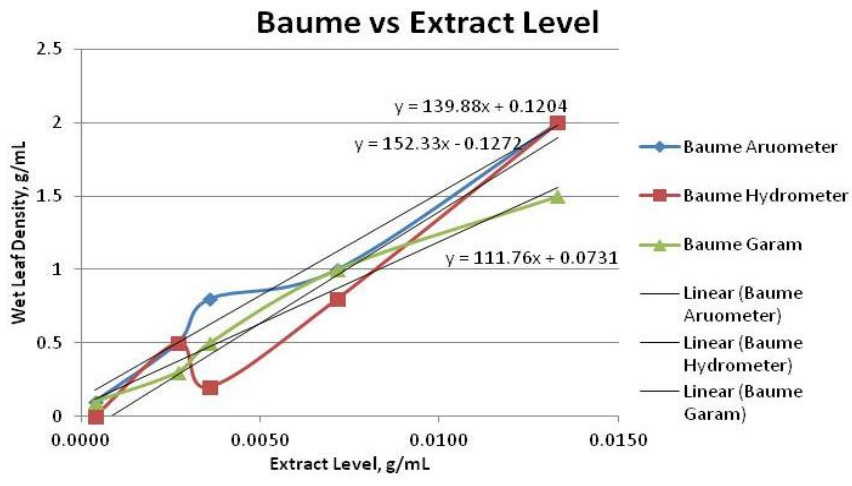

Fig. 2 Baume vs extract content of fresh mangrove leaves.

Samples tested with pycnometer, Baume and gravimetry were applied on mordant fabric for coloration observation. Each fabric was immersed for 10 minutes and then was dried. After that, the fabrics were fixated using 3 fixation agents made from lime, alum and lotus. This fixation process was intended to enhance color retention on the fabrics. Each fixation was observed to produce distinct coloration. From the brightness of the resulting colors, alum fixation resulted in the brightest colors compared to results from lime and lotus fixation. The result from lime fixation was observed to produce lighter color than the result from lotus fixation. The colors resulted from lime fixation were milky white and beige-brown. Alum fixation resulted in milky white and light beige coloration. Lotus fixation produced beige and yellowish-gray colors. The best hue and color retention was displayed by results of lotus fixation. This result is consistent with the result of a previous study by Pringgenies et al. (2017), color retention test of batik fixated by alum, lime and lotus fixation agents by washdry, wash dry iron, and air-dry treatments showed that lotus fixated batik showed the best color retention of the three.

To determine the optimal concentration, dyeing results on all fabrics were compared. Fresh mangrove leaves sample 3 was selected with Baume aurometer of 1 , Baume hydrometer of 0.8 , Baume salinity of 1 and the extract content of $0.0071 \mathrm{~g} / \mathrm{ml}$.

Tannic acid, commonly found in mangrove leaves and propagules, is a natural pigment of a brown hue and can be used as a material for natural dye. Tannic acid has a maximum wavelength of $743 \mathrm{~nm}$. Concentrated samples were screened using Spectro Vis-Plus for absorbance rate and maximum wavelength. The results of absorbance rate measurements were put into the equation $y=9.1714 x+0.0233$ with $r=0.999$. This equation serves to describe the standard curve for tannic acid compounds. Screening results for fresh mangrove leaves can be seen in Table 1 .

\section{Dried mangrove leaves test results}

The dried mangrove leaves showed water content of $18.4257 \%$ (g water/g dried leaves). Total of dye content obtained for dried mangrove leaves varied between $18 \%$ (g extract/g dried leaves) and $26 \%$ (g extract/g dried leaves) making the mean total for dye content of dried leaves calculated at 22\% (g extract/g dried leaves).
Table 1 Tannic acid content of fresh mangrove leaves.

\begin{tabular}{ccc}
\hline Sample & $\boldsymbol{Y}$, Absorbance & $\boldsymbol{X}$, Level $(\mathrm{mg} / \mathrm{mL})$ \\
\hline DB 0 & 0.1900 & 0.0183 \\
DB 1 & 0.5890 & 0.0618 \\
DB 2 & 0.3050 & 0.0308 \\
DB 3 & 0.5060 & 0.0527 \\
DB 4 & 1.0560 & 0.1127 \\
\hline
\end{tabular}

Samples of the dried leaves extract were collected at $11.4 \mathrm{~cm}, 8.1$ $\mathrm{cm}, 4.7 \mathrm{~cm}, 3 \mathrm{~cm}$, and $500 \mathrm{ml}$ of pan level. Samples were left to simmer, after which all were measured for density and extract content using pycnometer and Baume scale. Test results were recorded into figures between pycnometer vs extract content and Baume scale vs extract content. Based on the data described in Fig. 3, higher dried leaves extract meant higher density as well. This finding is consistent with the theory since extract content and density are supposed to be indicators of the amount of content in a material. Density and pycnometer vs extract content in dried mangrove leaves can be related with equation approach, with $y=0.426 x+0.984$.

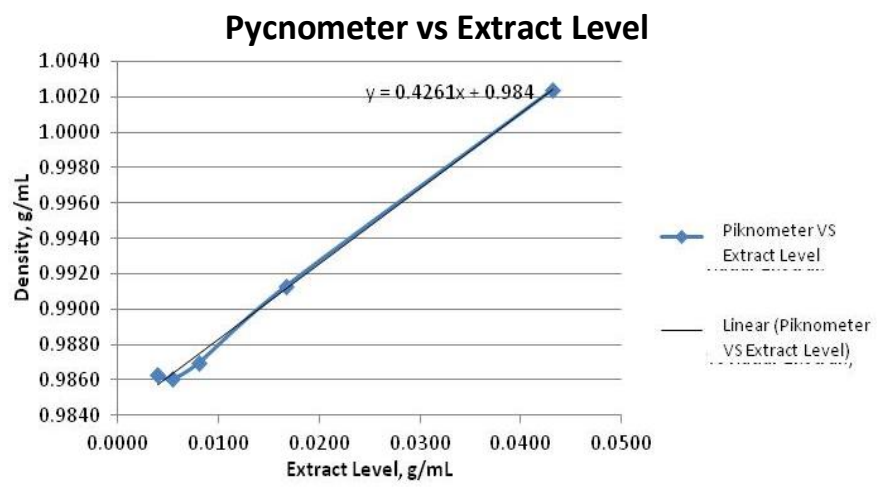

Fig. 3 Pycnometer vs extract content of dried mangrove leaves.

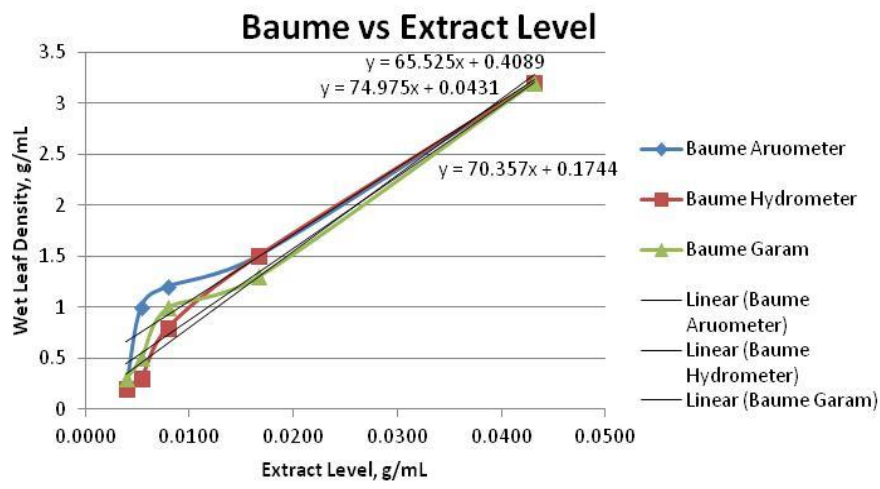

Fig 4. Baume scale vs extract content of dried mangrove leaves.

Data from Fig. 4 indicated that the extract content and density of dried mangrove leaves samples were proportionate. Baume aurometer measurements for dried leaves extract was approached with the equation $y=65.52 x+0.408$, whereas Baume hydrometer was approached by $y=74.97 x-0.043$. Baume salinity was approached by the equation $y=70.35 x+0.174$. Occurring coloration by lime fixation was pastel pink to brown-pink hue. Fixation by alum resulted in beige to light beige coloration and fixation by lotus produced moss gray to dark brown coloration. Dried leaves sample selected was sample no 2 with Baume aurometer of 1.2, Baume hydrometer of 0.8, Baume salinity of 1 and the extract content of $0.0080 \mathrm{~g} / \mathrm{ml}$. The values of the tannic acid content for the dry mangrove leaf samples are shown in Table 2. 
Table 2 Tannic acid content of dried mangrove leaves.

\begin{tabular}{ccc}
\hline Sample & $\boldsymbol{Y}$, absorbance & $\boldsymbol{X}$, Level $(\mathrm{mg} / \mathrm{mL})$ \\
\hline DK0 & 0.137 & 0.0125 \\
DK1 & 0.520 & 0.0543 \\
DK2 & 0.521 & 0.0544 \\
DK3 & 0.552 & 0.0578 \\
DK4 & 0.724 & 0.0765 \\
\hline
\end{tabular}

\section{Globular mangrove propagule test results}

The water content of the materials was measured at $16 \%$ (g water/g globular propagule). Total pigment content in sample 1 was measured at $18 \%$ (g extract/g globular propagule) and in sample 2 was measured at $17 \%$ (g extract/g globular propagule). Total mean content obtained for globular propagule was $17 \%$ (g extract/g globular propagule).

Extract samples of globular propagules were collected from the pan at $8.8 \mathrm{~cm}, 7.1 \mathrm{~cm}, 4.6 \mathrm{~cm}$ and $500 \mathrm{ml}$ levels. Samples were simmered down after which their density and contents were measured using pycnometer and Baume scale.

Fig. 5 showed that the relation between extract content and density of globular mangrove propagule materials was proportionate. The relation between density and pycnometer vs extract content can be approached by the equation $\mathrm{y}=0.539 \mathrm{x}+0.982$.

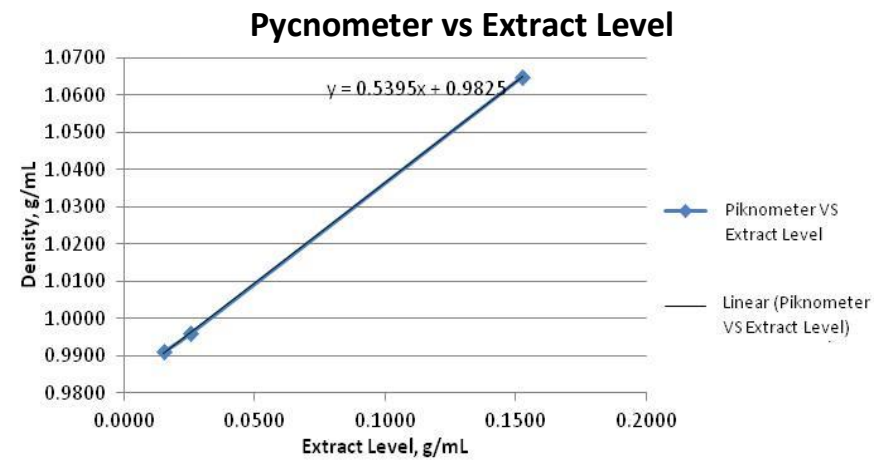

Fig 5. Pycnometer vs extract content of globular mangrove propagule.

Based on the data shown in Fig. 6, it was concluded that there was a proportionate relation between extract content and density of globular mangrove propagule. For globular mangrove propagule, the equations for measurements of Baume aurometer can be approached by $y=69.44 x+0.418$, Baume hydrometer can be approached by $y=$ $70.28 x+0.297$, and Baume salinity can be approached by $y=75.46 x$ +0.296 .

\section{Baume vs Extract Level}

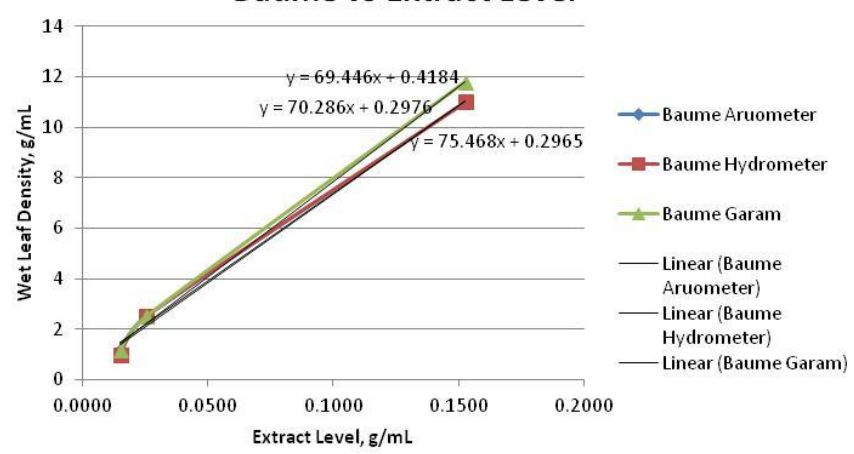

Fig 6. Baume vs extract content of globular mangrove propagule.

Fabric immersion using alum, lime and lotus based fixation resulted in the light to dark brown, beige to light brown, and moss gray to dark gray colorations, respectively. Sample 1 of globular mangrove propagule was selected with 2.5 of Baume aurometer, hydrometer, and salinity at $0.0255 \mathrm{~g} / \mathrm{ml}$ of extract content. The values of the tanni acid content for globular mangrove propagule samples are shown in Table 3.

Table 3 Tannic acid content of globular mangrove propagule.

\begin{tabular}{ccc}
\hline Sample & $\boldsymbol{Y}$, absorbance & $\boldsymbol{X}$, Level $(\mathbf{m g} / \mathbf{m L})$ \\
\hline BB & 0.813 & 0.0862 \\
Bbp1 & 0.902 & 0.0959 \\
Bbp2 & 1.012 & 0.1079 \\
\hline
\end{tabular}

\section{Torpedo-shaped mangrove propagule test results}

The water content measurement of torpedo-shaped mangrove propagule was at $14 \%$ (g water/g torp-shaped propagule). Total extract content for sample 1 and 2 were measured at $21 \%$ (g extract/g torp-shaped propagule) and 22\% (g extract/g torp-shaped propagule), respectively, making the total mean of extract content at $21 \%$ (g extract/g torp-shaped propagule). The extract samples were collected at pan levels of $8.8 \mathrm{~cm}, 7.1 \mathrm{~cm}, 4.6 \mathrm{~cm}$, and $500 \mathrm{ml}$. The samples were simmered down prior to density and content measurements by pycnometer and Baume scale. Results of the measurements can be seen in the Fig. 7.

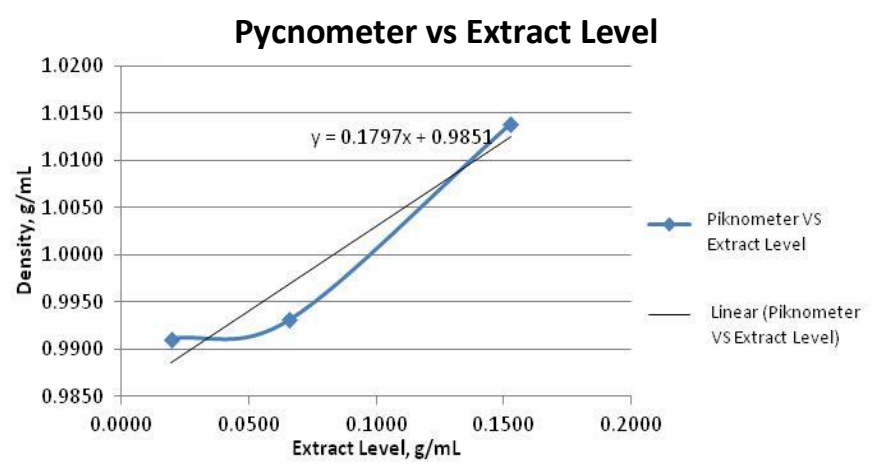

Fig. 7 Pycnometer vs extract content of torpedo-shaped mangrove propagule.

The data described in Fig. 7 indicated that there was a proportionate relationship between extract content and density of the torpedo-shaped mangrove propagule material. The relation between density and pycnometer $v s$ extract content of torpedo-shaped propagule in this study can be approached by $y=0.179 x+0.985$ equation.

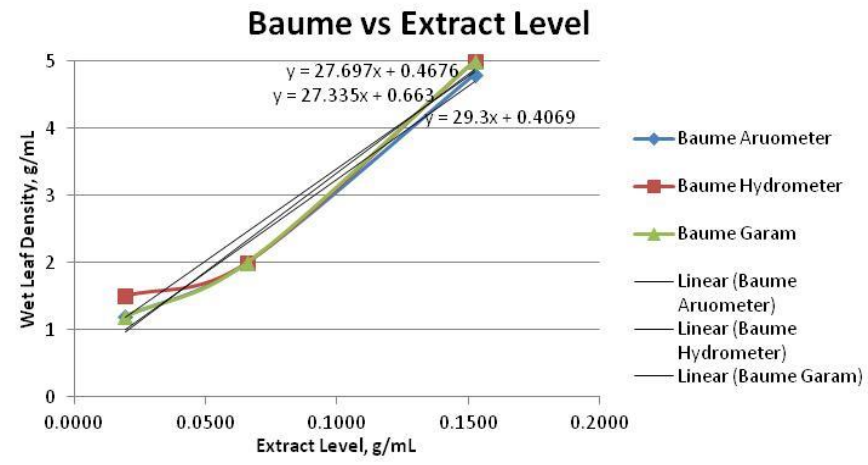

Fig 8. Baume vs extract content of torpedo-shaped mangrove propagule.

As seen in Fig. 8, the relationship between extract contents of torpedo-shaped mangrove propagule and its density was found to be proportionate. Measurements of torpedo-shaped mangrove can be 
approached by the equation $y=27.69 x+0.467$ for Baume aurometer, by the equation $y=27.33 x+0.663$ for Baume hydrometer, and by the equation $y=29.3 x+0.406$ for Baume salinity.

The coloration of fabrics resulted from lime fixation was light to dark brown. Alum and lotus fixation produced beige to light brown and moss gray to dark gray, respectively. The values of the tannic acid content of torpedo-shaped mangrove propagule is shown in Table 4.

Table 4 Tannic acid content of torpedo-shaped mangrove propagule.

\begin{tabular}{ccc}
\hline Sample & $\boldsymbol{Y}$, absorbance & $\boldsymbol{X}$, Level $(\mathbf{m g} / \mathbf{m L})$ \\
\hline BP & 1.712 & 0.1842 \\
Bpp1 & 1.754 & 0.1888 \\
Bpp2 & 1.843 & 0.1985 \\
\hline
\end{tabular}

The optimal concentration was selected based on the best color retention produced on fabric and the existence of solids. The optimal concentrations for fresh leaves, dried leaves, globular propagule and torpedo-shaped propagule were determined at $0.0071 \mathrm{~g} / \mathrm{ml}, 0.0080$ $\mathrm{g} / \mathrm{ml}, 0.0255 \mathrm{~g} / \mathrm{ml}$, and $0.0275 \mathrm{~g} / \mathrm{ml}$, respectively. The optimal concentration for mangrove propagule of both varieties was also found at $0.0275 \mathrm{~g} / \mathrm{ml}$. The optimal concentration for mangrove propagule was found to be at almost similar levels compared to that found for Dracaena. By using 5 Dracaena leaves, the optimal extraction time was obtained at 3 hours of extraction at $60{ }^{\circ} \mathrm{C}$ of temperature, with $600 \mathrm{rpm}$ speed and $200 \mathrm{ml}$ of ethanol solvent. These conditions yielded $1.29 \%$ of extracted chlorophyll (Yuniwati, et al. 2012). In another study, mangosteen peel extraction with ethanol was found to be impacted by acidity, storage conditions and time, as well as heating temperature and time. Yusuf et al (2017), in their study of optimal conditions on extractions and wool fabric immersion, discovered that the most optimal conditions were found at $\mathrm{pH} 2$, time at 45 minutes, the temperature at $90{ }^{\circ} \mathrm{C}$ and at $\mathrm{pH} 4$, time at 90 minutes and temperature at $90{ }^{\circ} \mathrm{C}$. In this study, the best dye quality made from mangrove waste was found at $70{ }^{\circ} \mathrm{C}$ of temperature.

Phytochemical screening is performed to determine secondary metabolites in plants, which can be useful in identifying the main class of its bioactive compounds. Secondary metabolites in mangrove leaves and barks were discovered using this method, of which results are displayed in Table 5 .

The screening detected significant result on tannin class, whereas screening of mangrove bark also resulted in the positive identification of quinone. Saponin, steroid, terpenoid, alkaloid, and flavonoid was not detected in both leaves and barks samples. Tannin screening on leaves and barks samples gave a strongly positive result, signified by greenish-black coloration after the 5 drops of $\mathrm{FeCl}_{3} 1 \%$ was added. Quinone screening of mangrove barks samples showed positive results from the occurrence of red coloration after 5 drops of $\mathrm{NaOH}$ solution were mixed. Flavonoid screening of both samples showed positive results after the occurrence of red coloration by introductions of 1 gram of Manganese powder and 5 drops of concentrated $\mathrm{HCl}$. However, this coloration was not found in the flavonoid screening of Cayratia trifolia (L.) Domin, with purplish-black coloration being the positive identifier instead. This is due to the existence of another compound in the fruit of the plant, namely, anthocyanin, which caused the distinct coloration instead of the commonly found red in the flavonoid-positive indicator (Neliyanti and Idiawati. N, 2014).

\section{Fractionation by chromatography}

The result of Column Chromatography showed that on leaf waste and skin is found in blackish green color and on the skin can be found in red. The results of this study by using the chromatography column make the color of batik waste a lot of choices.

\section{CONCLUSION}

The relation between extract content and density was found to be proportionate. Higher extract content resulted in darker colors. Immersion results using lime fixation of fresh mangrove leave-based dye, dried mangrove leave-based dye, globular mangrove propagulebased dye, and torpedo-shaped mangrove propagule-based dye were white to light brown to beige brown, pink beige to dark pink, light brown to dark brown, and light brown to dark brown respectively. Immersion results using alum fixation of fresh mangrove leave-based dye, dried mangrove leave-based dye, globular mangrove propagulebased dye, and torpedo-shaped mangrove propagule-based dye were white to light beige to beige, light beige to beige, beige to light brown, and beige to light brown respectively. Immersion results using lotus fixation of fresh mangrove leave-based dye, dried mangrove leavebased dye, globular mangrove propagule-based dye, and torpedoshaped mangrove propagule-based dye were yellow to gray, moss gray to dark brown, moss gray to dark gray, and gray to dark gray respectively. The further conclusion is the optimal concentration for fresh mangrove leave-based dye, dried mangrove leave-based dye, globular mangrove propagule-based dye, and torpedo-shaped mangrove propagule-based dye were measured at $0.0071 \mathrm{~g} / \mathrm{ml}, 0.0080$ $\mathrm{g} / \mathrm{ml}, \quad 0.0255 \mathrm{~g} / \mathrm{ml}$ (sample 1), and $0.0275 \mathrm{~g} / \mathrm{ml}$ respectively. Phytochemical screening results on mangrove leaves and barks showed significant positive results for tannin class, whereas mangrove bark also showed a positive result for quinone. The results of this study by using chromatographic columns make the color of batik waste a lot of choices.

\section{ACKNOWLEDGEMENT}

The authors would like to express the appreciation to those who helped support this research at Departement of Marine Science Diponegoro University, Hi-Link Project, DIKTI, and PUI (Pusat Unggulan IPTEKS Perguruan Tinggi Indonesia).

\section{REFERENCES}

Agustina, T. E., Nurisman, E., Prasetyowati, Haryani, N., Cundari, L., Novisa, A., Khristina, O. 2011. Pengolahan air limbah pewarna sintetis dengan menggunakan reagen fenton. Dalam: Prosiding Seminar Nasional AVoER ke-3, 26-27 October. Palembang, 260-266.

Bogoriani, N. W. 2010. Ekstraksi zat warna alami campuran biji pinang, daun sirih, gambir dan pengaruh penambahan $\mathrm{KMnO}_{4}$ terhadap pewarna kayu jenis Albasi. Jurnal Kimia. 4(2). Juli. P. 125-134.

Harbone, J. B. 1987. Metode Fitokimia. Penuntun Cara Modern Menganalisa Tumbuhan. Terbitan Kedua. ITB, Bandung, 6-15.

Harborne, J. B. 1984. Phytochemical Methods: A guide to modern technique of plant analysis. ( ${ }^{\text {nd }}$ ed.). Chapman and Hall, London. 19, 37-168.

Indrianingsih, A. W., Darsih, C. 2013. Natural dyes from plants extract and its applications in Indonesian textile small medium scale enterprise. Technical Implementation Unit for Chemical Engineering Processes, 11(1), 16-22.

Neliyanti, Idiawati, N. 2014. Ekstraksi dan uji stabilitas zat warna alami dari buah lakum (Cayratia trifolia (L.) Domin). Jurnal Kimia Khatulistiwa, 3(2), 30-37.

Table 5 Result of leaf and bark phytochemical screening.

\begin{tabular}{cccccccc}
\hline \multirow{2}{*}{ Type of Mangrove Waste } & \multicolumn{7}{c}{ Class of Secondary Metabolite Compounds } \\
\cline { 2 - 8 } & Tannin & Saponin & Steroid & Terpenoid & Alkaloid & Flavonoid & Quinone \\
\hline Leaf & ++ & - & - & - & - & - & - \\
Bark & ++ & - & - & - & - & + & + \\
Explanation & Green & - & - & - & - & Red & Red \\
\hline
\end{tabular}

Note: $(-)=$ not detected $\quad(+)=$ positive $\quad(++)=$ strong positive 
Pringgenies. D., Supriyantini, E., Azizah, R., Hartati, R., Irwani, Radjasa, O. K. 2013. Application of mangrove as natural dye for batik diservication at Gemawang Village, Semarang Regency [Conference Program and Abstracts]. In: 2nd Natural Pigments Conference for South-East Asia (NPSEA). 12-13 July. Universitas Ma Chung, Malang, pp.68.

Pringgenies. D, Pratiwi, A. H. D., Yudiati, E., Azizah, R., Susilo, E. S. 2017. Biopigment tracing of mangrove Rhizophora mucronata leaf and bark waste and its application for batik dyeing by multiple fixations. In: Proceeding of The $7^{\text {th }}$ Annual Basic Science International Conference. 7-8 March. Malang, Indonesia, 180-111. Retrieved from:
http://basic.ub.ac.id/files/proceeding/PROCEEDINGS-BASIC-2017VOL1.pdf

Yuniwati M., A. W. Kusuma, F. Yunanto. 2012. Optimasi kondisi proses ekstraksi zat pewarna dalam daun suji dengan pelarut etanol. Prosiding Seminar Nasional Aplikasi Sains \& Teknologi (SNAST) Periode III. 3 November. Yogyakarta, Indonesia. A.258 -263.

Yusuf. M, F. Mohammad., Shabbir. 2017. Eco-friendly and effective dyeing of wool with anthraquinone colorants extracted from Rubia cordifolia roots: Optimization, colorimetric and fastness assay. Journal of King-Saud University - Science. 29, 137-144. 